\title{
Mastery of one's domain is not the essence of management
}

\section{Article}

Published Version

Open Access

Sinnicks, M. (2014) Mastery of one's domain is not the essence of management. Business Ethics Journal Review, 2 (2). pp. 8-14. ISSN 2326-7526 doi: https://doi.org/10.12747/bejr2014.02.02 Available at https://centaur.reading.ac.uk/99736/

It is advisable to refer to the publisher's version if you intend to cite from the work. See Guidance on citing.

Published version at: https://bejreview.files.wordpress.com/2014/03/bejrv2n02sinnicks.pdf Identification Number/DOI: https://doi.org/10.12747/bejr2014.02.02 <https://doi.org/10.12747/bejr2014.02.02>

Publisher: Philosophy Documentation Center

All outputs in CentAUR are protected by Intellectual Property Rights law, including copyright law. Copyright and IPR is retained by the creators or other copyright holders. Terms and conditions for use of this material are defined in the End User Agreement.

\section{www.reading.ac.uk/centaur}

\section{CentAUR}

Central Archive at the University of Reading 
Reading's research outputs online 


\title{
Mastery of One's Domain Is Not the Essence of Management
}

\author{
Matthew Sinnicks ${ }^{1}$
}

A COMMENT ON Gregory Beabout (2012) "Management as a Domain-Relative Practice that Requires and Develops Practical Wisdom,” Bus Ethics $Q$ 22(2): 405-432.

\begin{abstract}
I attempt to cast doubt on Beabout's attempt to build on MacIntyre's ethical theory by accounting for management as a 'domain-relative' practice for three reasons: i) we can partially engage in practices, so if management can be accounted a practice there is no need to invoke domain-relativity; ii) management does not seem to be domain-relative in the same way that other examples of domain-relative practices might be; and iii) practical wisdom, which Beabout sees as key to management as a domain-relative practice, is adequately covered by MacIntyre's account of politics.
\end{abstract}

For AlASDAIR MAcInTyRe, we begin to acquire the virtues by engaging in what he calls 'practices', which he (MacIntyre 2007: 187) defines as:

any coherent and complex form of socially established co-operative human activity through which goods internal to that form of activity are realized in the course of trying to achieve those standards of excellence which are appropriate to, and partially definitive of, that form of activity,

${ }^{1}$ University of Hertfordshire. Email: m.i.sinnicks@herts.ac.uk 
with the result that human powers to achieve excellence, and human conceptions of the ends and goods involved, are systematically extended.

Paradigmatic examples of such activities include chess, fine arts, and philosophy. MacIntyre suggests that management cannot be a practice because it lacks distinctive internal goods, a claim supported by Beadle (2002). However, management scholars who find MacIntyre's basic ethical framework compelling have sought to challenge this exclusion, and to account for management in terms of practices (e.g., Moore 2002). One possible solution to this apparent stand-off can be found in Beabout's (2012) account of management as a 'domainrelative' practice. Beabout accepts that management per se does not possess distinctive internal goods, and so cannot be a practice in and of itself, but instead argues that we can retain the intuition that management can be ethically rich and rewarding, as practices are, without rejecting MacIntyre's moral philosophy by arguing that management should be regarded as a 'domain-relative' practice.

Domain-relativity, in Beabout's (2012: 406) sense, implies that such a practice "has its own internal standards of excellence and is always related to another particular domain.” Domain-relative practices are (2012: 414):

activities that 1) possess internal standards of excellence identifiable to practitioners, and 2) are always related to another particular domain. In each such case, familiarity with the particularities of the other related domain is an integral feature of the activity . . I I am proposing that "domain-relative practices" always interlock with other practices...one teaches a subject, writes or speaks on a topic, coaches a sport, and so forth.

In what follows I will offer three objections to Beabout's account:

i) we can partially engage in practices, so if management can be accounted a practice there will be no need to invoke domainrelativity;

ii) management does not seem to be domain-relative in the same way that other possible examples of domain-relative practices might be; and

iii) the virtues Beabout suggests his account can explain, in particular practical wisdom, fall under the remit of MacIntyre's account of politics, rendering the notion of management as a domainrelative practice redundant. 


\section{i) Engagement Can Be Partial}

While those with no experience of a particular practice are unqualified to pass judgement on it, those at the periphery of a particular practice remain engaged in that practice even without actually performing the activity which the practice essentially consists in. If, as MacIntyre (2007: 191) suggests, the audience at a concert is engaged in music, and "lovers of . . . a well-thrown pass" are engaged in football, then it seems engagement is primarily about membership of the relevant community. Therefore, in certain cases of what Beabout calls a domain-relative practice, individuals are actually engaged in the practice that constitutes the particular domain in question. This means we have no need to invoke domain-relativity to explain management. The basketball coach is engaged in basketball, and the physics teacher is engaged in physics. Managers, however, are not so engaged for there is, ex hypothesi, no practice that management counts as an engagement in. This is not to say that no managers are practitioners. The manager of a firm of architects might have a love of great architecture, and be motivated by the desire to institutionally sustain the practice of architecture. However, the admission that managers can also be practitioners does not give us any reason to make pronouncements about management as a whole, nor does it give us reason to think that manager-practitioners are such in virtue of the distinctly managerial elements of their role, and so those who would deny management the status of practice have, as yet, so reason to abandon that claim.

\section{ii) Absence of Domain-Relativity in Management}

Although I would regard a coach as partially engaged in the sport being coached, even if we accept that there are domain-relative practices, it is not clear that management belongs in this category because it seems to lack domain-relativity. Documentary making, for instance, may well be a domain-relative practice. A good documentary about a particular subject will have different characteristics from a documentary about another subject, so the practice is in some way domain relative because every documentary will have to do justice to its subject (i.e., domain), and yet documentary making has specifiable goods that are independent of any particular domain such as the intrinsic satisfaction of capturing the key features of a subject visually, and of selecting and editing material that adds up to a distinctly 
documentary-apt satisfying whole. Documentary makers will thus carefully research the domain in question, and will have no hope of achieving the goods internal to documentary making without a sound knowledge of the subject.

Beabout (2012: 415) makes a similar point about coaching. He argues that:

If someone is very good as a basketball coach, it does not follow that the same person would be very good as the coach of a golf squad or a swimming team. Excellence as a coach is intimately tied to the coach's familiarity with the particular sport.

Beabout makes a good point here, but it is not clear that it supports his argument for management as a domain-relative practice because unlike coaches, managers need not be familiar with the domain in question. Basketball is a practice with identifiable internal goods, which is why basketball coaches do not and cannot typically move into golf or swimming coaching. To understand the goods internal to a practice requires at least some experience, and to become sufficiently adept to coach others properly requires rather a lot. Managers, on the other hand, can more easily move from one industry to another, and management consultants can be drafted in by any company, regardless of whether or not that particular institution houses a practice. Management, therefore, seems to require neither a familiarity with the nature of the business they are working in nor for that business to be practice-based. This is not to say that such familiarity will not sometimes be advantageous, ${ }^{2}$ nor that exceptionally charismatic and motivating sports coaches cannot move into different sports, nor that some people are simply multi-talented and can master a variety of practices, but it tells against Beabout's account that managers changing from one industry to another occurs as frequently as it does. Top swimming coaches almost never become top basketball coaches. The internal goods, and the time and devotion required to achieve them, are just too different for such transitions to be easily achievable. Beabout's argument is thus susceptible to the general objection that management is not domain-relative.

2 Beabout gives the example of an electric company manager who was once a lineman, and whose practical experience allowed him to solve problems that had stumped other managers. Furthermore, within practices managers might require familiarity with the practice to excel as managers, but in such cases it is the partial engagement with the practice that is key. 
Beabout claims that just as we can judge basketball coaches by either success (in terms of victories, and therefore in terms of external goods) or excellence (according to the standards internal to coaching), a manager can be judged according to measurable outcomes or by standards of excellence. Beabout (2012: 418) describes managerial work as involving "budgeting, scheduling, hiring, firing, allocating, implementing, monitoring, correcting ... greeting, listening, planning, identifying, solving, communicating, motivating, delegating, mentoring, celebrating." Someone who possesses the skills needed to do all of those things well has a good chance of being a good manager, that is, of achieving Beabout's examples of goods internal to management, "administering and leading" (2012: 418), excellently, regardless of the domain. The tactical and technical insights required by an excellent swimming coach will be of almost no use to that coach if he or she attempted to break into the world of basketball coaching. Perhaps the ability to motivate players is a rhetorical skill common to both swimming and basketball coaching, but even then, the excellent swimming coach who is also an excellent orator but who knows nothing of basketball is unlikely to be able to excellently motivate basketball players, for whom the coach's ignorance of their sport will be obvious. An inspirational power company executive might be hired by any number of companies in any number of industries, but is unlikely to become the head coach of a sports team. By contrast, it is not uncommon for sports coaches to be asked to give talks to business leaders and business students. The distinction between practices and non-practices helps to explain this asymmetry.

\section{iii) MacIntyre's Politics}

Beabout (2012: 419) claims that MacIntyre "has done little to develop an account of practical wisdom as a virtue helpful for those ... charged with managing institutions that house social practices," and goes on to elaborate his own account of what managerial excellence involves. The crucial feature of management, according to Beabout (2012: 427), is that it requires practical wisdom:

In order to become excellent at managing, it is necessary to develop a set of character traits; chief among these is the virtue of practical wisdom. Practical wisdom is the habit of mind whereby one is excellent in each case at finding the available means to accomplish a worthy end. 
However practical wisdom is a virtue that is required to act excellently in any context. It will no doubt be required by virtuous managers as it is required by all virtuous people. Furthermore, the practical wisdom required by Beabout's account of management is rather like the virtues MacIntyre regards as being essential to politics. Beabout says MacIntyre (2007: 194) claims that institutions have "all the characteristics of a practice," but what MacIntyre (2007: 194) actually says is that "the making and sustaining of forms of human community - and therefore of institutions - itself has all the characteristics of a practice." This point makes sense only if we first understand the contrast MacIntyre draws between institutions and practices. Institutions, so MacIntyre argues, are primarily concerned with external goods (e.g., money, power, and prestige), whereas the defining characteristic of practices is their internal goods. Therefore, MacIntyre's point is that sustaining institutions which allow humans to cultivate the virtues and to achieve their good is a practice, and so managers who sustain these kinds of institutions will be engaged in a practice. Sustaining institutions in and of itself cannot be a practice because institutions can be oppressive or merely acquisitive. The name MacIntyre (2007: 195) gives to the practice of institutionally sustaining communities is 'politics', which has been a central theme in MacIntyre's work. So, contrary to Beabout's assertion, MacIntyre has devoted much of his life's work to providing an ethical framework which might prove 'helpful' to those who aim to sustain practicebased forms of human community.

In conclusion, while Beabout makes a laudable attempt to avoid the Scylla of MacIntyre's outright rejection of management and the Charybdis of an excessively broad conception of practices, it is not clear that he has provided a fully convincing account. I suggest that a more political understanding of good management may be a more promising avenue.

Received 3 March 2014 / Posted 17 March 2014

\section{REFERENCES}

Beabout, G. 2012. "Management as a Domain-Relative Practice that Requires and Develops Practical Wisdom.” Bus Ethics Q 22(2): 405-432.

Beadle, R. 2002. “The Misappropriation of MacIntyre”, Phil Mgmt 2(2): 45-54.

MacIntyre, A. 2007. After Virtue. 3e. London: Duckworth. 
Moore, G. 2002. "On the Implications of the Practice-Institution Distinction: MacIntyre and the Application of Modern Virtue Ethics to Business.” Bus Ethics Q 12(1): 19-32. 